\title{
MOTHERLAND IN DANGER: How Stalin Micromanaged the Media during the War With Nazi Germany and HuRt MobiLization Efforts
}

\author{
Karel C. Berkhoff
}

I f you lived, say, in Novosibirsk or Tashkent during World War II, what were you told? What did Soviet newspapers and radio tell Soviet civilians, and what did it all mean for the outcome of the war? The wartime archival record of the Soviet propaganda outlets and controlling agencies, including Stalin's personal file in the former party archives, is surprisingly small. For instance, only a tiny proportion of readers' letters and reports on meetings of newspaper editors with party ideologues have been preserved. The same applies to the archives of editorial boards; mainly, it seems, because there was no strict rule on archival storage and because the journalists themselves cared little about this. As for the propaganda texts themselves, the biggest loss occurred when the original typescripts of the central radio broadcasts from the first months of the war were deliberately destroyed in October 1941, when it seemed that Moscow might fall.

A close look reveals that during the war with Nazi Germany, known in Russia as the Great Patriotic War, Soviet propaganda was much more centralized than in Nazi Germany. Joseph Goebbels led the German Ministry of Propaganda, but he lacked dictatorial power; competing forces remained in place. In the Soviet Union, however, one man basically decided everything. Stalin created a central information bureau, instructed editors, studied drafts of newspaper articles, glanced at page proofs, and immensely tightened censorship. He squeezed out the voices of real people, quite contrary to the view that the war made him loosen his grip.

Stalin found keeping control more important than stimulating and mobilizing people, so in this sense, Soviet propaganda was more totalitarian than its notorious Nazi counterpart. The extreme centralization, as both an ideal and a practice, had no equal in wartime Europe. Nothing shows this better than the Soviet state's almost immediate confiscation of radio receivers from its own citizens; only wire radios remained. It was all because of fear. Stalin led a regime that had known for a long time, even under Vladimir Lenin, that its popular support was slim, and now, at war with Germany, he feared that his citizens might become less loyal to him. Stalin also feared that accurate information might benefit Nazi

propaganda or cause the Americans and other allies to reconsider their Soviet aid.

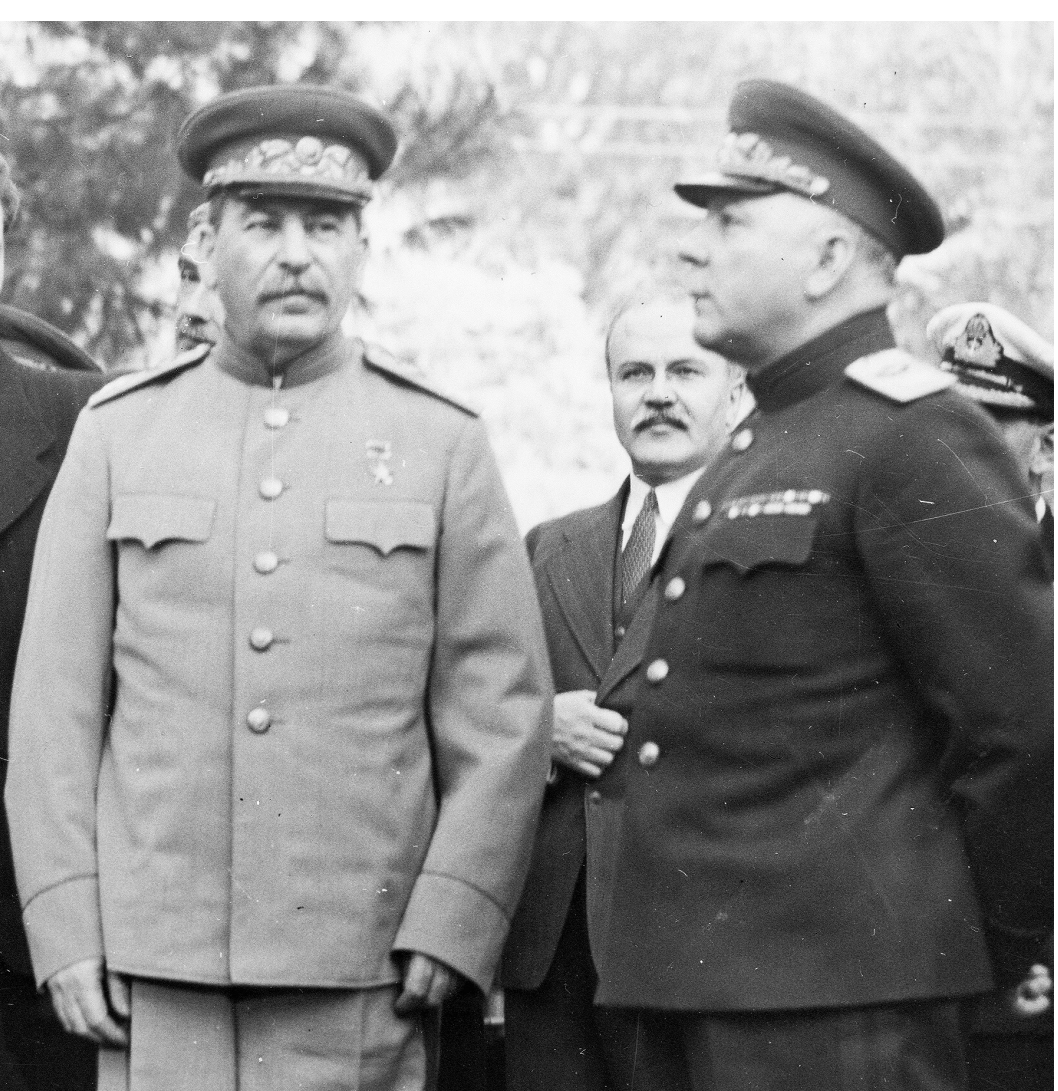

Tehran, December 1943. From left to right: Marshal Josef Stalin, Foreign Minister Molotov, General Voroshilov. Library of Congress, Prints and Photographs Division production number, LC-USZ62-132802].

There were stories about selfless war heroes, which people suspected were partly or wholly untrue, and if Moscow received information contradicting the tales-corpses not found, dead heroes turning out to be alive- - it was suppressed. Soviet citizens were also provided with many stories about traitors. In Germany, the UK, and the U.S., too, the media searched for and found war heroes and traitors. If British and American propaganda denigrated entire nations as enemies, for most of the war, Soviet propaganda also emitted hate speech - it encouraged and incited ethnic hatred and violence. In an ideological heresy tolerated by Stalin, the German people, not just their leaders or the "fascists," became evil incarnate.

Most surprising is the similar treatment of what we now call the Holocaust: how the Nazis_-assisted by many other Europeans-succeeded almost completely in murdering all the Jewish men, women, and children within their reach. Early on, Stalin and his associates were told by various sources that the Nazis were exterminating all Jews. But the media hardly ever highlighted this killing campaign. Stalin was aware that many of his associates and subjects were anti-Semitic. Telling the country about Jews would hurt the war effort

One could argue that propaganda that barely informed did not really hurt the war effort because the home country was under attack and the invaders' regime was more brutal and murderous than any earlier occupation in world history. It is true that eventually the "war of annihilation" declared by Adolf Hitler just had to be opposed. The danger underlined in Soviet propaganda was real, and Soviet citizens realized that, indeed, Nazi Germany offered them nothing but slavery and death. Stalin's propaganda told them that the "Hitlerites" were murdering innocent civilians, including women, children, and the elderly; soon rumors and first-hand accounts by refugees confirmed these tales. The entire country was under threat. Moreover, Stalin, in a rare brilliant stroke, made propaganda speak more of the "fatherland" and the "motherland" than of Russia, a word that alienated many non-Russian citizens. While Russian patriotism did flourish, the Georgian-born dictator restrained its chauvinistic version.

In various ways, the war propaganda of the Soviet Union resembled that of other belligerents. against those who were exterminating them, he seems to have assumed. Here, too, Soviet coverage resembled British and American reporting.

Yet overall, Stalin's war propaganda stands out from its contemporaries. There was a near-absence of real voices and real people-even Stalin himself hardly ever was heard on the radio. There was a condescending omission of facts known abroad: if the information bureau said nothing about some setback or success, the entire propaganda system stayed silent, unless the Kremlin gave special permission. Only after nine weeks of war was the loss of a city reported for the first time. The absence of real reporting on battles placed countless soldiers and civilians in danger. Soviet citizens generally did not expect to be informed in the first place, but quite a few were indignant. Silence and blatant lies hurt the morale and thus hampered mobilization.

Soviet reporting also was remarkable for its simplistic treatment of treason. Articles, broadcasts, and works of fiction called it criminal even to consider retreat or surrender. In most people's definition, 
heroism goes beyond ordinary obligations and cannot be demanded. Yet Soviet propaganda demanded heroism from everyone. As Pravda warned, all Red Army soldiers had to be "ready to die a hero's death." The media glorified invented tales of suicidal actions while presenting them as typical and only to be expected.

The contributions of the British, the Americans, the Canadians, and the Poles were underestimated to such a degree that the Red Army seemed to be fighting the Germans on its own. Stalin's prewar media had said that the world's first socialist society needed no foreign aid. Now the Soviet Union got all the credit. Portrayals of the Allies were mostly bland and never appealed to emotion. Thus when a Soviet trade union leader visited the UK and thanked them for founding a British committee to coordinate Soviet aid, Stalin personally edited the text for publication in Pravda. He replaced the speaker's "sincere gratitude" with a "feeling of satisfaction" and added a phrase belittling the aid as a "response to the most serious aid that the Soviet Union gave and is still giving to England by drawing off the main force of the Germans to the east and saving the English isles from invasion by the Hitlerite gangs and London from bombing by German planes."

The entirety of unoccupied Soviet territory was subordinated to the interests of the armed forces. Virtually all citizens were "mobilized" into forced labor - they had to work and had no say about the place and duration. In that sense Stalin was right to proclaim, on May Day 1942, the existence in the rear of a single lager, or camp. The propaganda willfully neglected the terrible suffering and famine in the hinterland, which remains little known even today. Instead, according to the propaganda, most workers and peasants were selfless patriots engaged in public campaigns for production records.

Another key flaw of Soviet propaganda was its style, exemplified by the highly artificial letters from citizens and soldiers read out on the radio. Next to nothing was natural in the way these letters were written, obtained, and edited, and the original writers no longer recognized their own material. Although Stalin seemed to think that the public letters to and from the front inspired and mobilized, their bone-dry style seriously hampered the cause.

So did the sparse content of reports on labor conditions. In fact, the main obstacle to labor mobilization through the media was the outlandish severity of the censors, who cut not only items on their black list but "all data that might indirectly allow conclusions revealing military secrets to be drawn." Many regional authorities, factory directors, and editors of local newspapers objected. They failed to see why (according to Moscow's rules) they could not report the identification numbers of factories or the names of their directors, if the central press was already doing so. A particularly strong complaint came from the city of Rostov on the Don, where censors banned reports about the bread factory simply because it supplied the armed forces. The regional leaders wrote angrily to the Central Committee, "Thanks to censorship, our Molot [Hammer] has turned into a pious old crazy woman-you won't find in it anything whatsoever that reflects our work in strengthening the city's defense. Our descendants will wonder: for sixteen months, the enemy stood at the gates of Rostov, people fought them with and without success, and Molot says nothing about it, nothing whatsoever, because censorship cuts so deep, far, and wide that any academic would be envious."

Soviet propaganda also failed entirely in achieving any semblance of dialogue between the famished peasants and the authorities, local or central. For a while, the party secretary of one oblast printed requests to local leaders to greet and congratulate the kolkhozniks on his behalf. This was in order, he added, because they had exceeded their production quotas and thus significantly strengthened the country's military might. Then the Central Committee squashed the initiative, for it expressed gratitude in the wrong direction. Stalin always spoke of indebtedness and obligation as a one-way street. Peasants had to obey the party-state, and like all Soviet citizens, were "selfless" subjects who owed everything to their authorities. No official could acknowledge their efforts, let alone thank them. Only Stalin could do that, and he rarely did.

A final and typically Soviet flaw was that newspapers and radio messages often literally did not arrive. Scarcity, technical problems, and poor and slow distribution caused many people to miss out entirely on print and radio propaganda.

Thus life in the rear was shaped less by propaganda than we might have expected, precisely because its context and contents were so totalitarian. Other factors were more important in shaping Soviet attitudes: the militarization of labor; the cruelty of Nazi Germany and its allies; and the tales heard from refugees, evacuees, railway employees, and hospitalized soldiers. Most Soviet citizens concluded that their fate under the Germans would be even worse than under Stalin. That awareness, deriving not just from propaganda but also from word-of-mouth communication, was the key reason why people rallied around the Soviet state and its armed forces. What saved Stalin's day was less his propaganda than the reality that Hitler's regime offered no livable alternative.

Karel Berkhoff is senior researcher at the NIOD Institute for War, Holocaust and Genocide Studies at the Royal Netherlands Academy of Arts and Sciences.

He is the author of Motherland in Danger: Soviet Propaganda during World War II (Harvard University Press, 2012) and Harvest of Despair:

Life and Death in Ukraine under Nazi Rule Belknap Press of Harvard University Press, 2004; 2008), recipient of the Fraenkel Prize in Contemporary History, Category $A$, and, in translation, shortlisted as Ukrainian Book of the Year, Category History.
DONATE TO THE HISTORICAL SOCIETY

The Historical Society is a non-profit, 501(c)3 organization. Membership dues account for only $25 \%$ of our total operating budget. We rely upon grants and individual contributions to fund our various activities. Your contribution enables the Society to publish two journals (Historically Speaking and the Journal of the Historical Society), and sponsors a biennial conference. Your contribution also supports history education in the public schools. The Society provides Historically Speaking at a subsidized rate to over 5,000 history teachers. Your contribution is tax deductable. The tax identification number of the Historical Society is 23-2857281.

Donate $\$ 50$ or more and receive your choice of two books from the Historians in Conversation series. To make your contribution and receive your free books, go to:

www.bu.edu/historic/donate

Thank you for supporting the Historical Society. We cannot exist without your support.

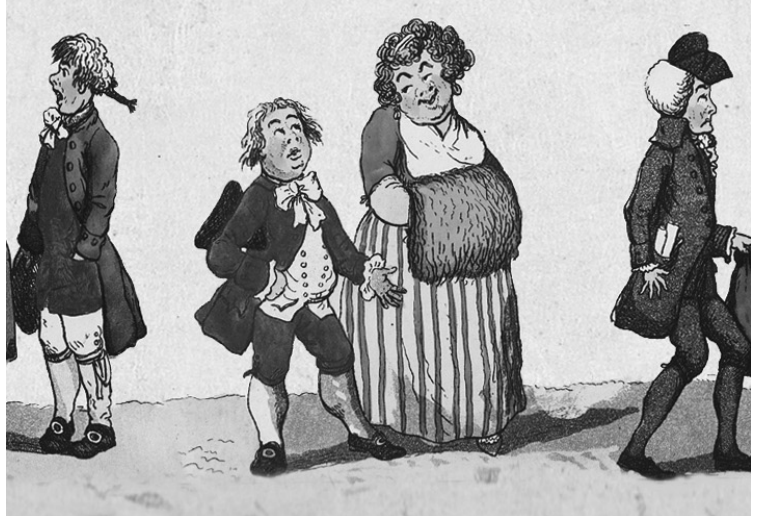

